\title{
Original paper \\ Unusual morphological forms of hodrušite from the Rozália vein, Hodruša-Hámre near Banská Štiavnica (Slovak Republic)
}

\author{
Jiří SEJKORA ${ }^{*}$, Martin ŠTEVKO², Daniel OZDÍN², Jaroslav PRŠEK³, Stanislav JELEŇ4,5 \\ ${ }^{1}$ Department of Mineralogy and Petrology, National Museum, Cirkusová 1740, 19300 Prague 9, Czech Republic; jiri_sejkora@nm.cz \\ ${ }^{2}$ Department of Mineralogy and Petrology, Faculty of Natural Sciences, Comenius University, Mlynská dolina G, 84215 Bratislava, Slovak \\ Republic \\ ${ }^{3}$ AGH, University of Science and Technology, Department of Economic Geology, Al. Mickiewicza 30, 43 309 Kraków, Poland \\ ${ }^{4}$ Faculty of Natural Sciences, Matej Bel University, Tajovského 40, 97401 Banská Bystrica, Slovak Republic \\ ${ }^{5}$ Geological Institute of Slovak Academy of Sciences, Dumbierska 1, 97401 Banská Bystrica, Slovak Republic \\ *Corresponding author
}

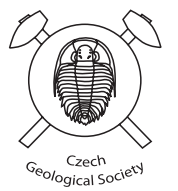

Rare Cu-Bi sulphosalt, hodrušite, occurs in the Rozália vein (levels X-XIV of the Rozália mine, Hodruša-Hámre ore deposit near Banská Štiavnica, central Slovakia) in two unusual morphological forms. The first type are brownish bronze thin acicular striated crystals, up to $3 \mathrm{~mm}$ long, in drusy cavities of quartz-hematite gangue, which are usually grouped into chaotic or irregular aggregates. The second hodrušite type comprises flattened columnar aggregates, up to $1.5 \mathrm{~cm}$ long, overgrown by hematite in quartz gangue. These aggregates are distinctly striated with brownish bronze colour and metallic lustre. Abundant W- and Al-rich hematite, chalcopyrite, kaolinite/dickite, siderite, baryte, rare bismuthinite and kupčíkite were found in the association. The earliest columnar aggregates of hodrušite are locally substantially replaced by bismuthinite; these hodrušite-bismuthinite aggregates are further intensively pushed back by hematite displaying $\mathrm{W}$ - and Al-rich zones. Acicular crystals of hodrušite in gangue cavities were later than bismuthinite and hematite and their formation was related to remobilisation of $\mathrm{Cu}$ and $\mathrm{Bi}$ from earlier altered gangue. Powder X-ray diffraction data and chemical composition of both hodrušite types are similar; their unit-cell parameters were refined (monoclinic space group $C 2 / m$ ) as: $a$ 17.552(5), $b 3.905(1), c$ 27.167(9) $\AA, \beta$ 92.44(3) ${ }^{\circ}, V 1860.5(9) \AA^{3}$ (acicular crystals) and $a 17.567(2)$, b 3.9151(7), c 27.155(5) $\AA, \beta$ 92.43(1) ${ }^{\circ}, V$ 1865.9(4) $\AA^{3}$ (columnar aggregates). Cu-for-Bi substitution is characteristic of both hodrušite types; it influences calculated $N_{\text {chem }}$ values $(0.98-1.33)$ to the point that it is impossible to distinguish hodrušite (ideal 1.5) from kupčíkite (ideal 1.0). The problem is resolved by Fe and Ag contents: kupčíkite has more than 2 at. \% Fe, cuprobismutite contains more than 2 at. \% of Ag; hodrušite usually has Ag and Fe contents below 2 at. \%. Hematite is remarkable for its high $\mathrm{WO}_{3}$ content reaching $4.96 \mathrm{wt}$ \% (0.04 apfu), extremely unusual of a hematite from hydrothermal vein mineralization. Tungsten probably enters the hematite structure via the $2 \mathrm{Fe}^{3+} \leftrightarrow \mathrm{W}^{6+}+\square$ substitution.

Keywords: hodrušite, kupčikite, cuprobismutite homologues, W-rich hematite, Hodruša-Hámre ore deposit, Slovak Republic Received: 10 March 2014; accepted: 30 December 2014; handling editor: R. Skála

\section{Introduction}

Rare Bi sulphosalt of the cuprobismutite homologous series, hodrušite, was described as a new species from V and VI levels of the Rozália vein located near Hodruša-Hámre in the Slovak Republic. In the holotype material, hodrušite forms irregular aggregates or, rarely, intergrowths of platy crystals, up to $5 \mathrm{~mm}$ in length. It occurs in quartz-hematite gangue together with chalcopyrite and wittichenite (Koděra et al. 1970). Besides the type locality, hodrušite was observed only occasionally. Hodrušite in association with sulphosalts of bismuthinite-aikinite series was described from Julcani ore district, Peru (Crowley et al. 1997). Lamellar aggregates of hodrušite together with makovickyite, cuprobismutite, paderraite and bismuthinite derivates were found in the Paulus mine at the Ocna de Fier skarn deposit, Romania (Cook and Ciobanu 2003). Hodrušite was also identified together with tetrahedrite and aikinite at the Kairagach gold-sulphide-telluride deposit, Uzbekistan (Kovalenker et al. 2003). Detailed study of hodrušite and other members of cuprobismutite homologous series by Topa et al. (2003a, b) was based on samples from Hodruša-Hámre (Slovakia), Felbertal near Salzburg (Austria), Swartberg (South Africa), Băiţa Bihor and Ocna de Fier (Romania). Silver-rich hodrušite associated with cuprobismutite and kupčíkite was described from $\mathrm{Ni}-\mathrm{Bi}-\mathrm{As}$ mineralization at Čierna Lehota in the Slovak Republic (Pršek et al. 2005). Hodrušite in association with kupčíkite, cuprobismutite and aikinite-series minerals was found in granitic pegmatites near Szklarska Poręba, Poland (Pieczka and Gołębiowska 2012). Occurrence of hodrušite was also reported from the El Quemado granitic pegmatite, Salta, Argentina (Márquez-Zavalía et al. 2012) and the Black Metals mine, Nevada, Alice mine, Colorado and Bisbee, Arizona (Anthony et al. 2003). 




Fig. 1a - Geological-structural sketch map of the central zone of the Štiavnica stratovolcano (after Lexa et al. 1999). b - Schematic E-W cross section of the Rozália vein (according to Koděra et al. 2005).

This paper presents data on unusual morphological types of hodrušite from the type locality, with particular focus on the chemical composition of hodrušite and associated minerals. It is a follow-up of a detailed study of hodrušite and a rich assemblage of associated sulphosalts from the gangue corresponding with the original hodrušite material (Jelen̆ et al. 2012). 


\section{Geological setting}

The base-metal $(\mathrm{Cu} \pm \mathrm{Pb}, \mathrm{Zn})$ Rozália vein mined by Rozália mine is situated about $2 \mathrm{~km} \mathrm{SE}$ of Hodruša-Hámre village in the Štiavnické vrchy Mts. (Slovak Republic) (GPS $48^{\circ} 27^{\prime} 25.01 " \mathrm{~N}, 18^{\circ} 51^{\prime} 10.11^{\prime \prime}$ E). Epithermal base- to precious-metal mineralization is a part of the extensive vein system of the Štiavnica-Hodruša ore field located in the central part of the Štiavnica stratovolcano (Fig. 1a). The system of epithermal veins evolved from, and was controlled by, faults related to resurgent horst tectonics in the central part of caldera. Associated hydrothermal activity led to the formation of an extensive epithermal system, including more than 120 veins and veinlets over an area of about $100 \mathrm{~km}^{2}$ (Lexa et al. 1999; Lexa 2001). On the basis of structure, vertical extent, spatial distribution and dominant mineral association, three types of epithermal veins were distinguished: (i) Štiavnica-type veins, which are sulphide-rich basemetal veins $\pm \mathrm{Au}$ located in the eastern/central part of the horst; (ii) Hodruša-type veins with $\mathrm{Ag}-\mathrm{Au} \pm$ base-metal mineralization in central/western part of the horst and (iii) Kremnica-type veins with $\mathrm{Au}-\mathrm{Ag}$ minerals related to the marginal faults of the horst (Lexa et al. 1999).

The Rozália vein is one of the main Štiavnica-type basemetal ore veins in the region of Hodruša-Hámre, known since the $17^{\text {th }}$ century. The vein is hosted in propylitized andesite and quartz-diorite porphyry (Koděra 1959). Main exploration and mining of this vein started in 1951 only and definitely ceased in 1990 (Koděra and Lexa 2010). Since 1992, the Rozália mine changed exploration and ore production from Rozália vein to the system of older subhorizontal intermediate-sulphidation, caldera-related veins with $\mathrm{Au}$ mineralization, which are being mined ever since (Koděra et al. 2005). The economically important part of the Rozália vein is more than $3 \mathrm{~km}$ long and $0.3-5 \mathrm{~m}$ thick (typically $0.3-1$ $\mathrm{m})$, generally trending $\mathrm{N}-\mathrm{S}$ and dipping $40-50^{\circ}$ to the $\mathrm{E}$ (Fig. $1 b)$. The structure of the vein filling is mostly brecciated or drusy (Koděra 1959). According to the same author, the vein filling was formed during the six mineralization periods and it rep-

Fig. 2 Rich group of brownish bronze acicular hodrušite crystals in drusy cavities of quartz-hematite gangue; width of image $4 \mathrm{~mm}$. resents deep (Cu-rich) part of the Štiavnica-type veins. The dominant and most important are the second (base-metal) period with galena, sphalerite and chalcopyrite in the upper part and the fourth (copper) period with chalcopyrite in the lower, northern and central parts of the vein. The gangue minerals are mainly quartz, carbonates (siderite and calcite) and hematite. Small amounts of baryte were also observed. The occurrence of bismuth sulphosalts, bornite, scheelite as well as hematite characterizes the deeper parts of the vein. Bismuth sulphosalts were formed during the fifth mineralization period (Koděra et al. 1970; Koděra 1981). Hodrušite, emplectite and wittichenite together with hematite and chalcopyrite are the most common minerals and $\mathrm{Cu}-\mathrm{Pb}-\mathrm{Bi}$ sulphosalts of the bismuthinite-aikinite series, sulphosalts of pavonite and cuprobismutite homologous series, galena-matildite solid solution, paděraite and berryite as well as Ag sulphosalts (polybasite, $\mathrm{Ag}$-tetrahedrite) occur in subordinate amounts (Koděra et al. 1970; Makovicky and MacLean 1972; Kovalenker et al. 1993; Jeleň and Háber 1995; Jeleň et al. 2012).

The newly studied samples were collected in 1988 and 1989 by M. Novák (Brno) and Z. Němec (Havírov) in the ore material from the Rozália vein; the samples come from large ore blocks (up to $1 \mathrm{~m}^{3}$ ) prepared for crushing before processing in the flotation plant. The stopes between the levels X and XIV of the Rozália mine were exploited at that time (P. Žitňan, pers. comm.). Hence this new material does not correspond to the samples from levels V and VI of the Rozália vein, from which hodrušite was originally described as a new species.

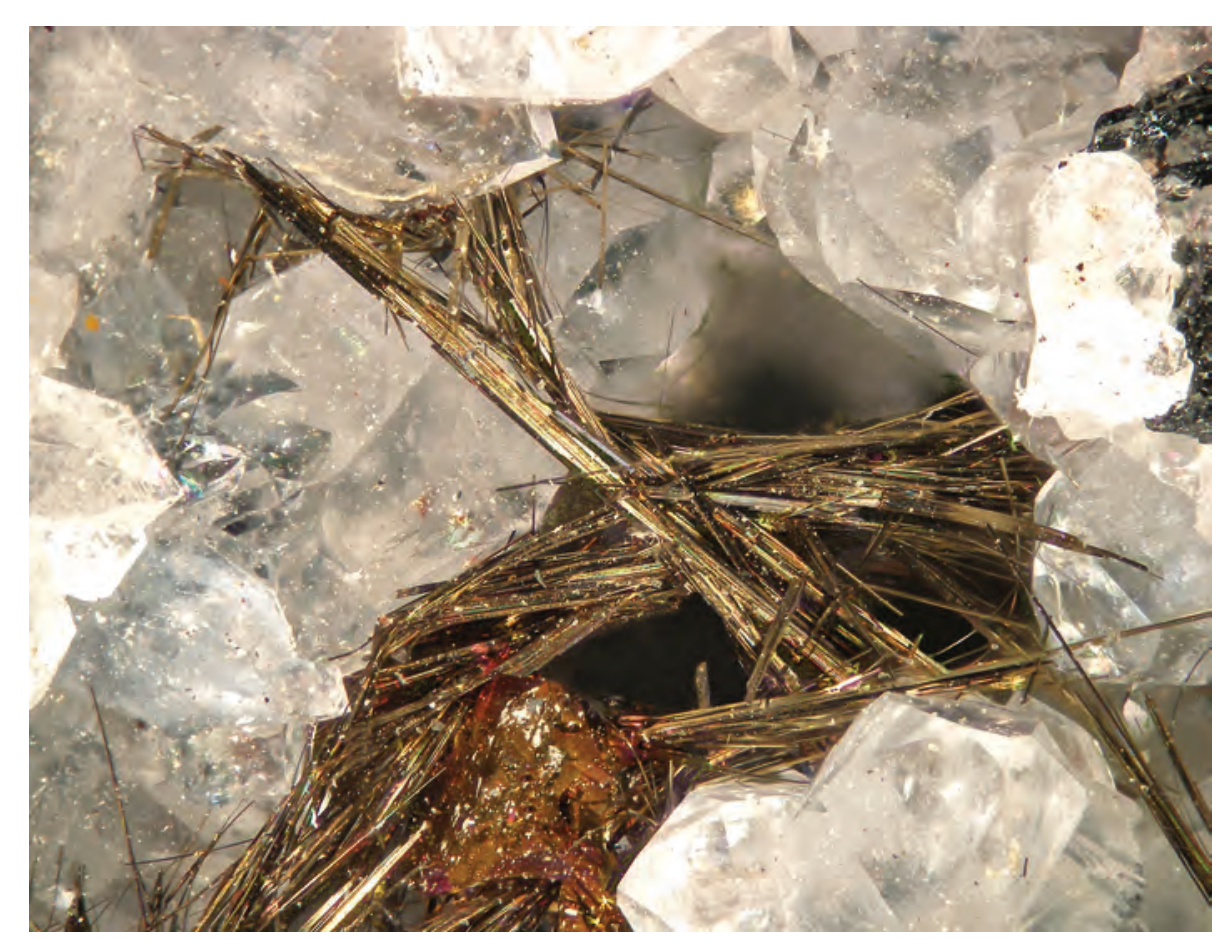




\section{Experimental techniques}

\subsection{Morphological study}

The hodrušite specimens were documented by an Olympus SZ61 optical microscope in combination with an Olympus SP-350 digital camera and QuickPHOTO MICRO 2.2 software (Faculty of Natural Sciences, Comenius University, Bratislava). Depth of field of the photos was controlled by stacking a number of co-axial pictures using the Deep Focus 3.1. software. Polished sections were prepared for optical investigation and chemical analysis using standard diamond-polishing techniques. Optical properties in reflected light were observed with a Nikon Eclipse ME600 microscope.

\subsection{X-ray powder diffraction study}

X-ray powder diffraction patterns were obtained from hand-picked samples using a Bruker D8 Advance diffractometer equipped with a solid-state 1D LynxEye detector using $\mathrm{CuK}_{\alpha}$ radiation (National Museum, Prague). In order to minimize the background, the powdered samples were placed on the surface of a flat silicon wafer from acetone suspension. The positions and intensities of diffractions were found and refined using the Pearson VII profile-shape function of the ZDS program package (Ondruš 1993), and the unit-cell parameters were refined by the least-squares program by Burnham (1962).

\subsection{Chemical analyses}

Quantitative chemical composition of hodrušite and associated minerals were determined with a Cameca SX100 electron-probe microanalyser (Faculty of Science, Masaryk University Brno), operated in the wavelengthdispersive mode at the following conditions ( $\mathrm{DL}=$ detection limit). Sulphosalts: $25 \mathrm{kV}, 20 \mathrm{nA}$, electron-beam diameter less than $1 \mu \mathrm{m}$ and standards: $\operatorname{Ag}\left(\operatorname{Ag} L_{\alpha}, \mathrm{DL} 0.11\right)$, Bi (Bi $M_{\beta}$ DL 0.20), CdTe ( $\mathrm{Cd} L_{\beta}$ DL 0.05), Co $\left(\mathrm{CoK}_{\alpha} \mathrm{DL}\right.$ 0.02), $\mathrm{Cu}\left(\mathrm{CuK} K_{\alpha} \mathrm{DL} 0.04\right), \mathrm{FeS}_{2}\left(\mathrm{Fe} K_{\alpha} \mathrm{DL} 0.03, \mathrm{SK}_{\alpha} \mathrm{DL}\right.$ $0.03), \mathrm{HgTe}\left(\mathrm{HgM}_{\alpha} \mathrm{DL} 0.07\right)$, pararammelsbergite $\left(\mathrm{NiK}_{\alpha}\right.$ DL 0.03, AsL $\left.L_{\beta} \mathrm{DL}^{\alpha} 0.14\right), \mathrm{PbCl}_{2}\left(\mathrm{ClK}_{\alpha} \mathrm{DL} 0.02\right), \mathrm{PbSe}^{\alpha}$ $\left(\mathrm{Pb} M_{\alpha} \mathrm{DL} 0.07, \mathrm{Se} L_{\beta} \mathrm{DL} 0.07\right), \mathrm{Sb}\left(\mathrm{Sb} L_{\beta} \mathrm{DL} 0.07\right)$ and $\mathrm{ZnS}$ (ZnK $K_{\alpha}$ DL 0.03); hematite: $15 \mathrm{kV}, 20 \mathrm{nA}$, electronbeam diameter less than $1 \mu \mathrm{m}$ and standards: sanidine $\left(\mathrm{AlK} K_{\alpha} \mathrm{DL} 0.02, \mathrm{Si}_{\alpha} \mathrm{DL} 0.03\right), \mathrm{MgO}\left(\mathrm{MgK}_{\alpha} \mathrm{DL} 0.02\right)$, chromite (CrK $K_{\alpha}$ DL 0.02), Sn ( $\mathrm{Sn} L_{\alpha}$ DL 0.04), almandine (FeK $K_{\alpha}$ DL 0.04), W (WL DL 0.11), spessartine $\left(\mathrm{MnK}_{\alpha} \mathrm{DL}\right.$ 0.04), titanite ( $\mathrm{TiK}_{\alpha} \mathrm{DL} 0.09, \mathrm{CaK}_{\alpha} \mathrm{DL} 0.02$ ), columbite $\left(\mathrm{NbL} L_{\alpha} \mathrm{DL} 0.14\right), \mathrm{ScVO}_{4}\left(\mathrm{ScK}_{\alpha} \mathrm{DL} 0.03\right)$ and $\mathrm{Ta}_{2} \mathrm{O}_{5}\left(\mathrm{Ta}_{\alpha}\right.$ DL 0.14). Elements above that are not included in tables of analytical data were measured but their contents were below detection limit. Measured data were corrected using PAP software (Pouchou and Pichoir 1985).

\section{Results and discussion}

\subsection{Minerals of the cuprobismutite homologous series (hodrušite, kupčíkite)}

Two morphological types of hodrušite occur in the drusy cavities of the quartz-hematite gangue, which occasion-

Tab. 1 X-ray powder pattern of hodrušite (columnar aggregates) from Hodruša-Hámre

\begin{tabular}{|c|c|c|c|c|c|c|}
\hline $\mathrm{h}$ & $\mathrm{k}$ & l & $\mathrm{d}_{\text {obs. }}$ & $\mathrm{I}_{\text {obs. }}$ & $\mathrm{d}_{\text {calc. }}$ & $I_{\text {calc. }}^{\dagger}$ \\
\hline 2 & 0 & 3 & 6.173 & 21 & 6.169 & 36 \\
\hline 4 & 0 & 0 & 4.383 & 9 & 4.388 & 7 \\
\hline 4 & 0 & $\overline{1}$ & 4.354 & 6 & 4.361 & 12 \\
\hline 4 & 0 & $\overline{2}$ & 4.229 & 10 & 4.228 & 6 \\
\hline 1 & 1 & $\overline{2}$ & 3.681 & 12 & 3.687 & 11 \\
\hline 1 & 1 & 2 & 3.677 & 7 & 3.669 & 5 \\
\hline 4 & 0 & 4 & 3.616 & 53 & 3.615 & 59 \\
\hline 1 & 1 & 3 & 3.508 & 7 & 3.508 & 17 \\
\hline 2 & 0 & 7 & 3.489 & 10 & 3.491 & 13 \\
\hline 4 & 0 & $\overline{5}$ & 3.484 & 17 & 3.485 & 23 \\
\hline 1 & 1 & $\overline{4}$ & 3.344 & 8 & 3.342 & 4 \\
\hline 3 & 1 & $\overline{1}$ & 3.240 & 12 & 3.240 & 39 \\
\hline 2 & 0 & $\overline{8}$ & 3.208 & 100 & 3.209 & 40 \\
\hline 1 & 1 & 5 & 3.111 & 29 & 3.111 & 100 \\
\hline 3 & 1 & $\overline{3}$ & 3.085 & 9 & 3.085 & 50 \\
\hline 0 & 0 & 9 & 3.014 & 10 & 3.014 & 10 \\
\hline 4 & 0 & $\overline{7}$ & 2.967 & 20 & 2.968 & 11 \\
\hline 6 & 0 & 0 & 2.925 & 12 & 2.925 & 12 \\
\hline 6 & 0 & $\overline{2}$ & 2.885 & 6 & 2.885 & 17 \\
\hline 3 & 1 & $\overline{5}$ & 2.820 & 14 & 2.820 & 19 \\
\hline 3 & 1 & 5 & 2.763 & 6 & 2.762 & 1 \\
\hline 6 & 0 & $\overline{4}$ & 2.729 & 10 & 2.728 & 26 \\
\hline 5 & 1 & $\overline{2}$ & 2.582 & 3 & 2.582 & 11 \\
\hline 5 & 1 & 2 & 2.550 & 9 & 2.551 & 28 \\
\hline 6 & 0 & 7 & 2.2893 & 19 & 2.2886 & 12 \\
\hline 8 & 0 & $\overline{1}$ & 2.1944 & 10 & 2.1942 & 7 \\
\hline 2 & 0 & 12 & 2.1670 & 7 & 2.1673 & 26 \\
\hline 5 & 1 & 7 & 2.1355 & 5 & 2.1359 & 9 \\
\hline 3 & 1 & $\overline{10}$ & 2.1082 & 8 & 2.1083 & 20 \\
\hline 7 & 1 & 3 & 2.0385 & 6 & 2.0401 & 6 \\
\hline 5 & 1 & $\overline{9}$ & 2.0071 & 3 & 2.0063 & 20 \\
\hline 0 & 2 & 0 & 1.9564 & 15 & 1.9576 & 37 \\
\hline 5 & 1 & 9 & 1.9449 & 4 & 1.9446 & 13 \\
\hline 7 & 1 & 5 & 1.9449 & 4 & 1.9444 & 17 \\
\hline 6 & 0 & $\overline{11}$ & 1.9260 & 3 & 1.9262 & 7 \\
\hline 8 & 0 & $\overline{8}$ & 1.8792 & 3 & 1.8787 & 6 \\
\hline 9 & 1 & $\overline{3}$ & 1.7263 & 4 & 1.7261 & 8 \\
\hline 9 & 1 & 2 & 1.7229 & 15 & 1.7230 & 12 \\
\hline 4 & 2 & 4 & 1.7210 & 7 & 1.7214 & 15 \\
\hline 3 & 1 & $\overline{14}$ & 1.6824 & 3 & 1.6825 & 3 \\
\hline 10 & 0 & 4 & 1.6824 & 3 & 1.6819 & 6 \\
\hline 2 & 2 & $\overline{8}$ & 1.6720 & 5 & 1.6712 & 13 \\
\hline
\end{tabular}

${ }^{\dagger}$ theoretical data calculated (Yvon et al. 1977) from crystal structure information of hodrušite (Topa et al. 2003a) 

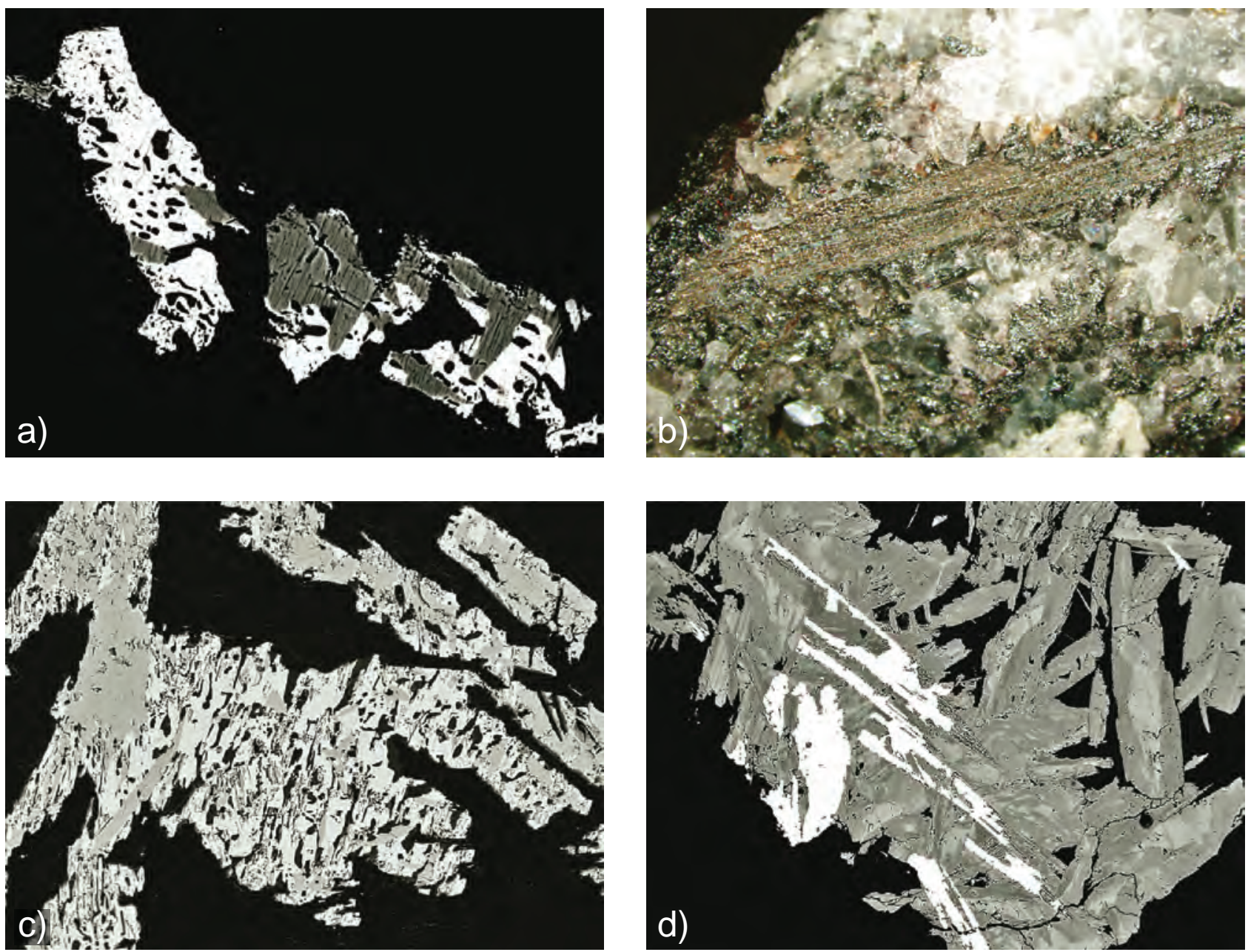

Fig. 3a - Hodrušite (grey) replacing earlier bismuthinite (white); BSE image; width of image $150 \mu \mathrm{m}$; $\mathbf{b}$ - Flattened columnar brownish bronze hodrušite aggregate in quartz-hematite gangue; width of image $1.8 \mathrm{~cm}$. c - Hodrušite (dark grey) partly replaced by aggregates of later bismuthinite (light grey); BSE image, width of image $300 \mu \mathrm{m}$. d - Aggregates of hodrušite/bismuthinite (white) intensively pushed back by later zoned hematite (grey); BSE image, width of image $1.7 \mathrm{~mm}$.

ally contains aggregates of massive chalcopyrite up to $2 \mathrm{~cm}$ across. The first type is represented by brownish bronze acicular hodrušite crystals up to $3 \mathrm{~mm}$ in length. Crystals are often striated and usually grouped into chaotic or irregular aggregates (Fig. 2). The drusy cavities of gangue are up to $1.5 \mathrm{~cm}$ across and, besides hodrušite, they also contain well developed crystals of transparent quartz up to $2 \mathrm{~mm}$ long, metallic tabular crystals or rosettes of hematite $(<2 \mathrm{~mm})$, aggregates of brownish-yellow siderite discs as well as rarely observed well developed crystals of chalcopyrite $(<3 \mathrm{~mm})$ and white tabular crystals of baryte $(<5 \mathrm{~mm})$. The acicular crystals of hodrušite grew on aggregates where hodrušite partially replaces bismuthinite at the cavities' walls (Fig. 3a). At margins of these acicular crystals, some $<10 \mu \mathrm{m}$ wide lamellar zones with chemical composition of kupčíkite were occasionally found.

The second type of hodrušite forms flattened columnar aggregates up to $1.5 \mathrm{~cm}$ in length (Fig. 3b) overgrown by hematite in quartz-hematite gangue. The hodrušite aggregates are distinctly striated with brownish bronze
Tab. 2 Unit-cell parameters of hodrušite (for monoclinic space group $C 2 / m$ )

\begin{tabular}{|c|c|c|c|c|c|}
\hline & Hodruša-Hámre [1] & Hodruša-Hámre [2] & Hodruša-Hámre [3] & Felbertal & Swartberg \\
\hline & this paper & this paper & $\begin{array}{c}\text { Kupčík and } \\
\text { Makovicky (1968) }\end{array}$ & $\begin{array}{l}\text { Topa et al. } \\
\text { (2003a) }\end{array}$ & $\begin{array}{l}\text { Topa et al. } \\
\text { (2003a) }\end{array}$ \\
\hline$a[\AA]$ & $17.567(2)$ & $17.552(5)$ & $17.58(5)$ & $17.562(1)$ & $17.527(3)$ \\
\hline$b[\AA]$ & $3.9151(7)$ & $3.905(1)$ & $3.93(1)$ & $3.9201(3)$ & $3.901(6)$ \\
\hline$c[\AA]$ & $27.155(5)$ & $27.167(9)$ & $27.21(5)$ & $27.150(2)$ & $27.120(4)$ \\
\hline$\beta\left[^{\circ}\right]$ & $92.43(1)$ & $92.44(3)$ & $92.1(2)$ & $92.561(1)$ & $92.343(7)$ \\
\hline$V\left[\AA^{3}\right]$ & $1865.9(4)$ & $1860.5(9)$ & 1879 & $1867.3(4)$ & $1852.9(6)$ \\
\hline
\end{tabular}

[1] columnar aggregates; [2] acicular crystals; [3] data transformated from space group A2/m given by Kupčík and Makovicky (1968) 

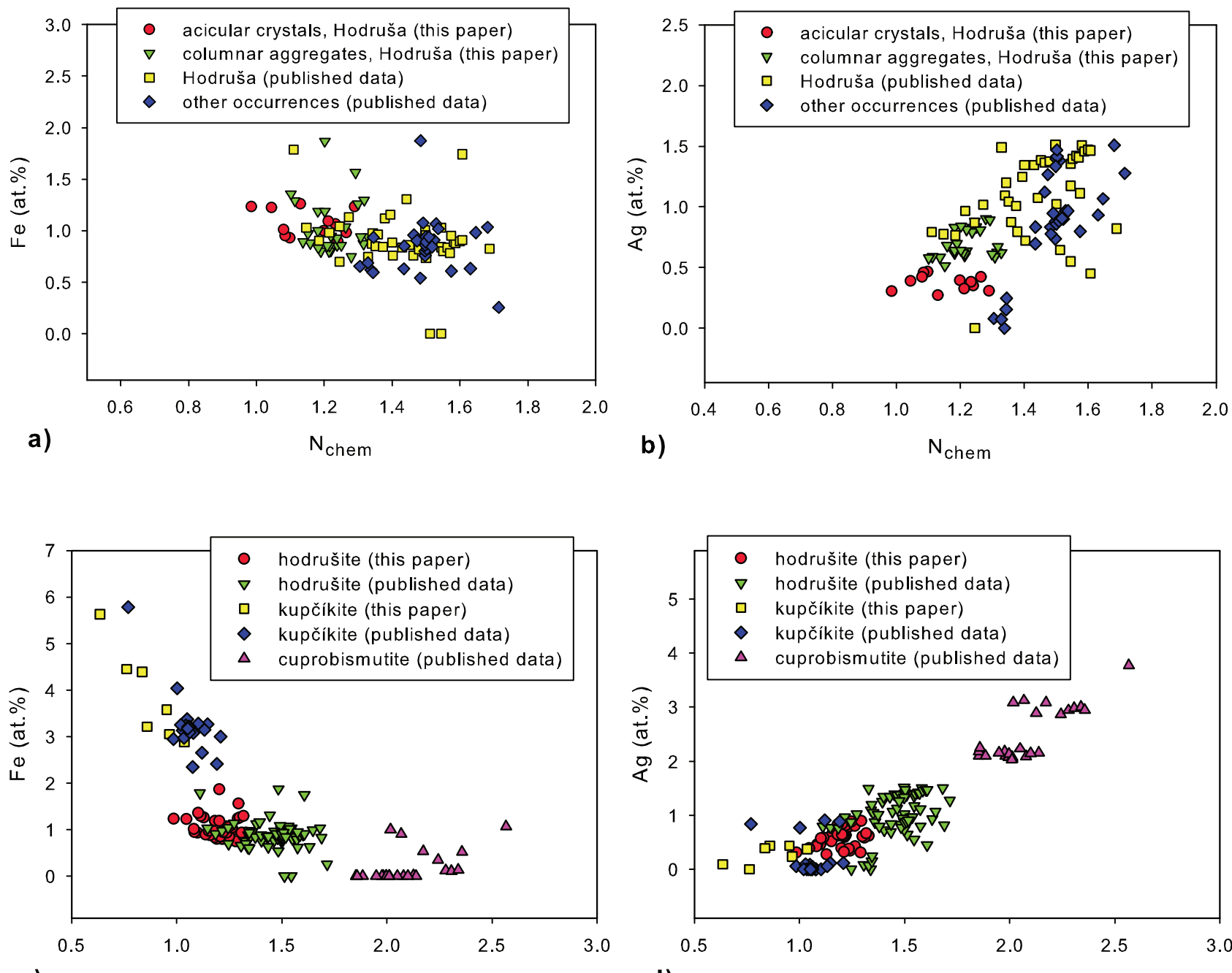

c)

$\mathrm{N}_{\text {chem }}$

d)

$\mathrm{N}_{\text {chem }}$

Fig. 4 Chemical composition of the cuprobismutite homologous series. Hodrušite: $\mathbf{a}-N_{\text {chem }}$ vs. Fe (at. \%) graph; b $-N_{c h e m}$ vs. Ag (at. \%) graph. Data from Hodruša-Hámre (this paper; Makovicky and MacLean 1972; Kovalenker et al. 1993; Topa et al. 2003a; Jeleň et al. 2012) and other occurrences (Cook and Ciobanu 2003; Topa et al. 2003a, b; Pršek et al. 2005; Márquez-Zavalía et al. 2012; Pieczka and Gołębiowska 2012). All members of the cuprobismutite homologous series: c $-N_{\text {chem }}$ vs. Fe (at. \%) graph; d $-N_{\text {chem }}$ vs. Ag (at. \%) graph. Published data sources: hodrušite (Makovicky and MacLean 1972; Kovalenker et al. 1993; Cook and Ciobanu 2003; Topa et al. 2003a, b; Pršek et al. 2005; Jeleň et al. 2012; Márquez-Zavalía et al. 2012; Pieczka and Gołębiowska 2012); kupčíkite (Topa et al. 2003a, b; Jeleň et al. 2012; Pieczka and Gołębiowska 2012); cuprobismutite (Cook and Ciobanu 2003; Topa et al. 2003a, b; Pršek et al. 2005; Jeleň et al. 2012; Pieczka and Gołębiowska 2012).

colour and metallic lustre. In the association, metallic aggregates of hematite up to $2 \mathrm{~cm}$, chalcopyrite grains reaching $1 \mathrm{~mm}$ and white earthy aggregates of kaolinite/ dickite up to $5 \mathrm{~mm}$ across were observed. The columnar hodrušite is extensively replaced by later bismuthinite (Fig. 3c); these hodrušite-bismuthinite aggregates are strongly pushed back by zoned hematite (Fig. 3d). In the hodrušite aggregates, there are only few occurrences of marginal lamellar zones up to $40 \mu \mathrm{m}$ wide, with the chemical composition of kupčíkite.

Powder X-ray data acquired from both hodrušite types are very close to each other. Positions of diffraction maxima match the only data published so far for this mineral (Koděra et al. 1970), using 57.3 and 114.7 $\mathrm{mm}$ powder film cameras, and differ significantly from the theoretical data for kupčíkite given by Topa et al. (2003b). Comparing the experimental pattern with that calculated from the crystal structure data of hodrušite (Topa et al. 2003a), significant differences in intensities of individual diffraction maxima were observed (see Tab. 1). This effect cannot be explained by a simple preferred sample orientation. It might be caused by the acicular shape of hodrušite crystals. Similar situation was also described for another fibrous sulphosalt marrucciite (Sejkora et al. 2011). The refined unit-cell parameters (Tab. 2) are consistent with those reported previously for hodrušite samples (Kupčík and Makovicky 1968; Topa et al. 2003a). 

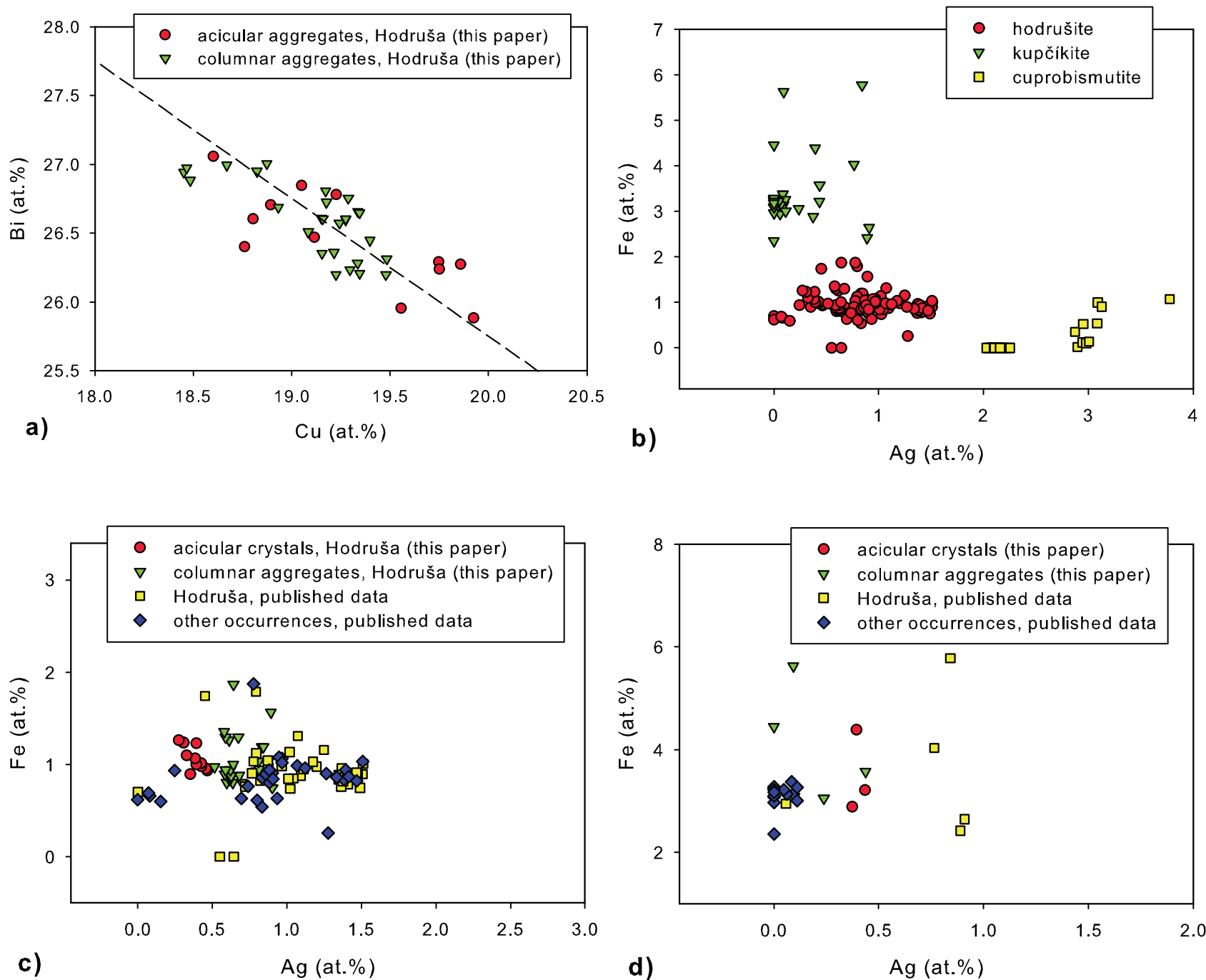

c)

$\mathrm{Ag}($ at. $\%)$

d)

Fig. 5a-Cu vs. Bi (at. \%) graph for studied hodrušite from Hodruša-Hámre (this paper); dashed line corresponds to an ideal Cu-for-Bi substitution. b- Ag vs. Fe (at. \%) graph for all members of cuprobismutite homologous series The same data sources as for Fig. 4c-d. c - Ag vs. Fe (at. \%) graph for hodrušite. The same data sources as for Fig. 4a-b. d - Ag vs. Fe (at. \%) graph for kupčíkite from Hodruša-Hámre (this paper; Jeleň et al. 2012) and from other occurrences (Topa et al. 2003a, b; Pieczka and Gołębiowska 2012).

General formula of minerals of the cuprobismutite homologous series can be expressed as $(\mathrm{Cu}, \mathrm{Fe})_{8}$ $(\mathrm{Bi}, \mathrm{Sb}, \mathrm{Ag}, \mathrm{Pb}, \mathrm{Cd})_{10+4(\mathrm{~N}-1)}(\mathrm{S}, \mathrm{Se})_{4 \mathrm{~N}+16}$; the $N_{\text {chem }}$ number of cuprobismutite homologues is defined by the relation 2 ("Bi"/“Cu")-1.5; where " $\mathrm{Bi}$ " is $\mathrm{Bi}+\mathrm{Sb}+\mathrm{Ag}+\mathrm{Pb}+$ $\mathrm{Cd}+\mathrm{Zn}$ and " $\mathrm{Cu}$ " is $\mathrm{Cu}+\mathrm{Fe}$ (Topa et al. 2003a). On this basis, kupčíkite with an ideal formula $\left(\mathrm{Cu}_{3.4} \mathrm{Fe}_{0.6}\right)_{\Sigma 4}$ $\mathrm{Bi}_{5} \mathrm{~S}_{10}$ is a homologue with $N_{\text {chem }}=1$, hodrušite $(\mathrm{Cu}, \mathrm{Fe})_{8}$ (Bi,Ag) ${ }_{12} \mathrm{~S}_{22}$ has $N_{\text {chem }}=1.5$, and cuprobismutite $\mathrm{Cu}_{8}$ (Bi, Ag) ${ }_{14} \mathrm{~S}_{24}$ is a homologue with $N_{\text {chem }}=2$.

The chemical composition of both newly studied hodrušite types is - with the exception of minor $\mathrm{Ag}$ contents - very similar (Tab. 3). Calculated $N_{\text {chem }}$ values (0.98-1.29 for acicular crystals; $1.10-1.33$ for columnar aggregates) are anomalously low compared to the ideal hodrušite $\left(N_{\text {chem }}=1.5\right)$ (Fig. $\left.4 \mathrm{a}-\mathrm{b}\right)$. Considering our and published data for minerals of the cuprobismutite homologous series (Fig. 4c-d), it is concluded that the calculated $N_{\text {chem }}$ values cannot be used for unambiguous determination of hodrušite from kupčíkite. The anomalous $N_{\text {chem }}$ values are, according to Topa et al. (2003a), caused by a $\mathrm{Cu}$-for-Bi substitution, as discovered by the crystal structure study of $\mathrm{Cu}$-enriched hodrušite from Swartberg, South Africa (with $N_{\text {chem }} \sim 1.3$ ). Our hodrušite samples indicate a large extent of this isomorphism (Fig. 5a) influencing the calculated $N_{\text {chem }}$ values significantly.

Minor contents of Fe and $\mathrm{Ag}$ (Fig. 5b), corresponding to $\mathrm{Fe}$-for- $\mathrm{Cu}$ and $\mathrm{Ag}$-for-Bi substitutions, characterize individual minerals of the cuprobismutite homologous series (Topa et al. 2003a, b). Kupčíkite shows an increased Fe content (more than $\sim 2$ at. \%), Ag content is low (up to 1 at. \%); cuprobismutite contains only little Fe (be- 
Tab. 3 Chemical composition of hodrušite (wt. \% and apfu based on 42 apfu)

\begin{tabular}{|c|c|c|c|c|c|c|c|c|c|c|c|c|}
\hline & mean $^{\mathrm{a}}$ & 1 & 2 & 3 & 4 & 5 & mean $^{\mathrm{b}}$ & 6 & 7 & 8 & 9 & 10 \\
\hline$\overline{\mathrm{Ag}}$ & 0.48 & 0.49 & 0.35 & 0.44 & 0.53 & 0.38 & 0.86 & 0.73 & 0.64 & 1.13 & 1.11 & 0.76 \\
\hline $\mathrm{Fe}$ & 0.68 & 0.79 & 0.82 & 0.58 & 0.64 & 0.80 & 0.65 & 0.88 & 0.63 & 0.48 & 1.01 & 0.60 \\
\hline $\mathrm{Pb}$ & 0.10 & 0.00 & 0.00 & 0.17 & 0.24 & 0.16 & 0.09 & 0.00 & 0.17 & 0.00 & 0.11 & 0.15 \\
\hline Cd & 0.08 & 0.07 & 0.06 & 0.08 & 0.06 & 0.06 & 0.08 & 0.19 & 0.00 & 0.09 & 0.07 & 0.07 \\
\hline $\mathrm{Zn}$ & 0.05 & 0.00 & 0.00 & 0.00 & 0.13 & 0.14 & 0.00 & 0.00 & 0.00 & 0.00 & 0.00 & 0.00 \\
\hline $\mathrm{Cu}$ & 14.11 & 14.52 & 14.21 & 13.99 & 13.85 & 13.68 & 13.94 & 14.34 & 14.17 & 14.12 & 13.53 & 13.53 \\
\hline $\mathrm{Bi}$ & 64.02 & 63.43 & 64.71 & 64.83 & 64.46 & 65.45 & 64.02 & 63.86 & 63.53 & 64.70 & 64.99 & 64.34 \\
\hline Se & 0.87 & 0.85 & 0.77 & 0.91 & 0.97 & 0.78 & 0.61 & 0.59 & 0.55 & 0.54 & 0.63 & 0.65 \\
\hline $\mathrm{S}$ & 19.16 & 19.06 & 19.51 & 19.16 & 19.26 & 19.17 & 19.13 & 19.34 & 19.50 & 19.24 & 18.97 & 19.00 \\
\hline Total & 99.53 & 99.21 & 100.43 & 100.16 & 100.15 & 100.63 & 99.38 & 99.93 & 99.19 & 100.29 & 100.42 & 99.09 \\
\hline$\overline{\mathrm{Cu}}$ & 8.069 & 8.295 & 8.028 & 8.001 & 7.898 & 7.813 & 8.009 & 8.125 & 8.074 & 8.054 & 7.756 & 7.841 \\
\hline $\mathrm{Fe}$ & 0.445 & 0.515 & 0.529 & 0.376 & 0.413 & 0.519 & 0.424 & 0.570 & 0.408 & 0.314 & 0.657 & 0.394 \\
\hline "Cu" & 8.515 & 8.811 & 8.558 & 8.378 & 8.311 & 8.332 & 8.433 & 8.695 & 8.483 & 8.368 & 8.413 & 8.236 \\
\hline$\overline{\mathrm{Bi}}$ & 11.136 & 11.021 & 11.117 & 11.276 & 11.174 & 11.365 & 11.180 & 11.006 & 11.003 & 11.224 & 11.328 & 11.337 \\
\hline $\mathrm{Ag}$ & 0.160 & 0.164 & 0.115 & 0.147 & 0.178 & 0.129 & 0.292 & 0.243 & 0.216 & 0.379 & 0.375 & 0.261 \\
\hline $\mathrm{Pb}$ & 0.017 & 0.000 & 0.000 & 0.031 & 0.042 & 0.028 & 0.017 & 0.000 & 0.030 & 0.000 & 0.019 & 0.027 \\
\hline Cd & 0.025 & 0.023 & 0.019 & 0.025 & 0.021 & 0.019 & 0.025 & 0.061 & 0.000 & 0.028 & 0.023 & 0.023 \\
\hline $\mathrm{Zn}$ & 0.026 & 0.000 & 0.000 & 0.000 & 0.072 & 0.078 & 0.000 & 0.000 & 0.000 & 0.000 & 0.000 & 0.000 \\
\hline "Bi" & 11.364 & 11.208 & 11.251 & 11.479 & 11.487 & 11.619 & 11.514 & 11.311 & 11.249 & 11.631 & 11.745 & 11.648 \\
\hline$\overline{\mathrm{Se}}$ & 0.398 & 0.390 & 0.351 & 0.420 & 0.445 & 0.359 & 0.281 & 0.267 & 0.253 & 0.247 & 0.292 & 0.301 \\
\hline S & 21.723 & 21.587 & 21.840 & 21.724 & 21.757 & 21.690 & 21.772 & 21.727 & 22.012 & 21.754 & 21.550 & 21.816 \\
\hline $\mathrm{S}+\mathrm{Se}$ & 22.121 & 21.978 & 22.191 & 22.144 & 22.202 & 22.049 & 22.054 & 21.995 & 22.264 & 22.001 & 21.842 & 22.117 \\
\hline$N_{\text {chem }}$ & 1.17 & 1.04 & 1.13 & 1.24 & 1.26 & 1.29 & 1.23 & 1.10 & 1.15 & 1.28 & 1.29 & 1.33 \\
\hline
\end{tabular}

low 1 at. \%) and Ag content is higher than $\sim 2$ at. \%. Hodrušite analyses fall at the junction of the trends observed in kupčíkite and cuprobismutite. It always contains less than 2 at. \% of $\mathrm{Ag}$ and Fe (Fig. 5b). While iron contents in both newly studied hodrušite types (Fig. 5c) are mutually comparable (acicular aggregates: 0.90-1.26, columnar aggregates: $0.75-1.56$ at. \% $\mathrm{Fe})$; columnar aggregates are slightly richer in Ag than the acicular crystals $(0.51-0.90$ vs. $0.27-0.47$ at. $\% \mathrm{Ag}$, respectively). As shown in Fig. $5 \mathrm{~b}-\mathrm{c}$, the $\mathrm{Fe}$ and $\mathrm{Ag}$ contents are more reliable for distinguishing individual members of the cuprobismutite homologous series than the calculated $N_{\text {chem }}$ values, which can be substantially influenced by the $\mathrm{Cu}$-for-Bi substitution (Fig. 4c-d).

$\mathrm{Pb}$-for-Bi substitution is insignificant in our hodrušite; variable contents less than 0.15

Tab. 4 Chemical composition of kupčíkite (wt. \% and apfu based on 19 apfu)

\begin{tabular}{|c|c|c|c|c|c|c|c|c|}
\hline & mean $^{\dagger}$ & 1 & 2 & 3 & 4 & 5 & 6 & 7 \\
\hline$\overline{\mathrm{Ag}}$ & 0.36 & 0.48 & 0.55 & 0.50 & 0.30 & 0.56 & 0.00 & 0.12 \\
\hline $\mathrm{Fe}$ & 2.60 & 1.93 & 2.11 & 2.90 & 2.01 & 2.39 & 3.00 & 3.84 \\
\hline $\mathrm{Pb}$ & 0.02 & 0.00 & 0.00 & 0.11 & 0.00 & 0.00 & 0.00 & 0.00 \\
\hline $\mathrm{Cd}$ & 0.14 & 0.20 & 0.14 & 0.07 & 0.10 & 0.13 & 0.19 & 0.14 \\
\hline $\mathrm{Zn}$ & 0.15 & 0.00 & 0.00 & 0.00 & 0.26 & 0.10 & 0.36 & 0.35 \\
\hline $\mathrm{Cu}$ & 13.72 & 13.45 & 14.08 & 13.70 & 13.70 & 13.64 & 13.81 & 13.68 \\
\hline $\mathrm{Bi}$ & 63.19 & 63.95 & 62.56 & 64.06 & 63.17 & 64.30 & 62.55 & 61.75 \\
\hline Se & 0.55 & 0.51 & 0.80 & 0.80 & 0.38 & 0.52 & 0.42 & 0.42 \\
\hline $\mathrm{S}$ & 19.74 & 20.33 & 19.21 & 19.09 & 19.59 & 19.76 & 20.05 & 20.16 \\
\hline Total & 100.46 & 100.85 & 99.44 & 101.22 & 99.51 & 101.39 & 100.38 & 100.46 \\
\hline$\overline{\mathrm{Cu}}$ & 3.435 & 3.354 & 3.583 & 3.455 & 3.479 & 3.411 & 3.417 & 3.350 \\
\hline $\mathrm{Fe}$ & 0.740 & 0.548 & 0.610 & 0.834 & 0.580 & 0.679 & 0.845 & 1.069 \\
\hline "Cu" & 4.174 & 3.902 & 4.194 & 4.289 & 4.059 & 4.090 & 4.262 & 4.419 \\
\hline$\overline{\mathrm{Bi}}$ & 4.810 & 4.850 & 4.843 & 4.914 & 4.878 & 4.889 & 4.707 & 4.598 \\
\hline $\mathrm{Ag}$ & 0.053 & 0.071 & 0.083 & 0.075 & 0.045 & 0.083 & 0.000 & 0.018 \\
\hline $\mathrm{Pb}$ & 0.001 & 0.000 & 0.000 & 0.008 & 0.000 & 0.000 & 0.000 & 0.000 \\
\hline Cd & 0.019 & 0.028 & 0.019 & 0.010 & 0.014 & 0.018 & 0.026 & 0.019 \\
\hline $\mathrm{Zn}$ & 0.037 & 0.000 & 0.000 & 0.000 & 0.065 & 0.024 & 0.087 & 0.084 \\
\hline “ $B i "$ & 4.921 & 4.949 & 4.945 & 5.007 & 5.003 & 5.014 & 4.820 & 4.718 \\
\hline Se & 0.111 & 0.103 & 0.163 & 0.163 & 0.078 & 0.104 & 0.083 & 0.082 \\
\hline $\mathrm{S}$ & 9.794 & 10.046 & 9.695 & 9.542 & 9.860 & 9.791 & 9.835 & 9.780 \\
\hline $\mathrm{S}+\mathrm{Se}$ & 9.904 & 10.149 & 9.858 & 9.705 & 9.938 & 9.895 & 9.918 & 9.862 \\
\hline$N_{\text {chem }}$ & 0.86 & 1.04 & 0.86 & 0.83 & 0.97 & 0.95 & 0.76 & 0.64 \\
\hline
\end{tabular}

at. $\% \mathrm{~Pb}$ were detected in both types. Higher $\mathrm{Pb}$ in minerals of this group (e.g., Pršek et al. 2005) can indicate the presence of other structurally close mineral phases - pizgrischite (c. 2 wt. \% Pb, Meisser et al. 2007) or paděraite (c. 7 wt. \% Pb, Topa and Makovicky 2006). Selenium content in the hodrušite columnar aggregates $(0.5-0.8$ wt. \%) is similar to that in sulphosalts from the hodrušite type material (Jelen̆ et al. 2012); acicular

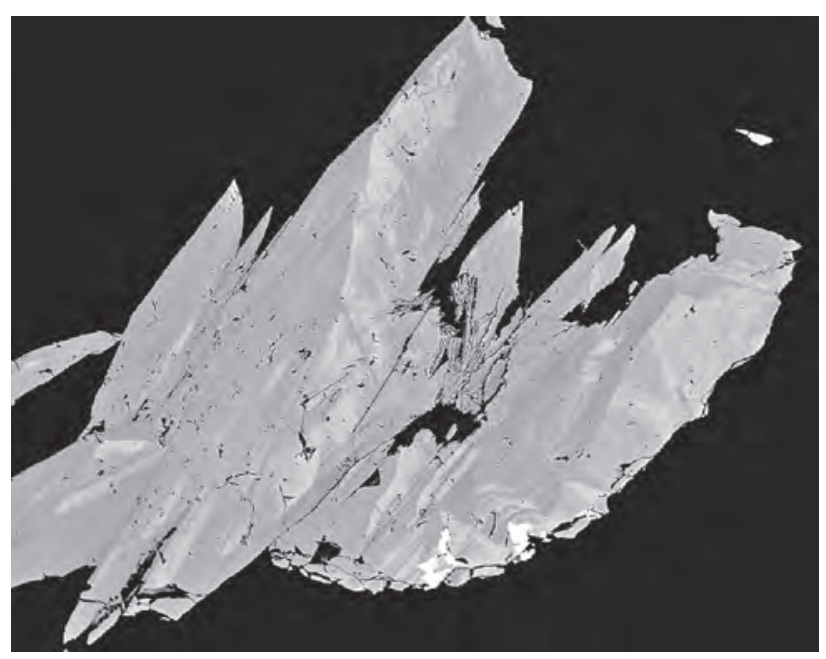

Fig. 6 Strongly zoned tabular crystals of hematite with tiny hodrušite-bismuthinite aggregates (white); BSE image, width of image $1 \mathrm{~mm}$. 
Unusual morphological forms of hodrušite from Hodruša-Hámre

crystals are slightly enriched in Se (0.7-1.0 wt. \%).

The calculated $N_{\text {chem }}$ values for the kupčíkite rarely observed here (Tab. 4), 0.64-1.04, indicate a $\mathrm{Cu}$-for-Bi substitution. The Fe (2.9-5.6 at. \%) and Ag (up to 0.4 at. \%) contents correspond to the values found in kupčíkite from Hodruša-

Tab. 5 Unit-cell parameters of bismuthinite (for orthorhombic space group Pnma)

\begin{tabular}{lccccc}
\hline & Hodruša & synt. & Felbertal & Tasna & Tasna \\
\hline & this paper & $\begin{array}{c}\text { Topa et al. } \\
(2002)\end{array}$ & $\begin{array}{c}\text { Topa et al. } \\
(2002)\end{array}$ & $\begin{array}{c}\text { Kyono and } \\
\text { Kimata (2004) }\end{array}$ & $\begin{array}{c}\text { Kyono and } \\
\text { Kimata (2004) }\end{array}$ \\
\hline$n_{\text {aik }}$ & $3.1-7.6$ & 0 & 10.6 & 0 & 0 \\
\hline$a[\AA]$ & $11.3245(7)$ & $11.314(1)$ & $11.337(3)$ & $11.316(3)$ & $11.345(3)$ \\
$b[\AA]$ & $3.9839(6)$ & $3.9853(4)$ & $3.991(1)$ & $3.9709(2)$ & $3.994(1)$ \\
$c[\AA]$ & $11.1617(7)$ & $11.163(1)$ & $11.187(3)$ & $11.178(2)$ & $11.193(4)$ \\
$V\left[\AA^{3}\right]$ & $503.57(7)$ & 503.34 & 506.17 & $502.3(2)$ & $507.2(2)$ \\
\hline
\end{tabular}

-Hámre (Fig. 5d) but are significantly higher than those published for kupčíkite from other localities (Topa et al. 2003a, b; Pieczka and Gołębiowska 2012).

\subsection{Bismuthinite}

Rare bismuthinite forms aggregates with acicular hodrušite (Fig. 3a) on the cavity walls in the quartzhematite gangue. Bismuthinite is more abundant in association with columnar aggregates of hodrušite, where it forms irregular grains up to $0.2 \mathrm{~mm}$ across, with the hodrušite being overprinted by bismuthinite (Fig. 3c). The hodrušite-bismuthinite aggregates are intensively replaced by zoned hematite (Fig. 3d)

$\mathrm{X}$-ray powder diffraction data for the bismuthinite match the reference patterns from the ICDD PDF2 database (43-1471). The refined unit-cell parameters are consistent with the data published for this mineral species (Tab. 5).

The empirical formula $\mathrm{Cu}_{\mathrm{x}} \mathrm{Pb}_{\mathrm{y}} \mathrm{Bi}_{8-1 / 2(\mathrm{x}+\mathrm{y})} \mathrm{S}_{12}$ was used for calculation of bismuthinite on the basis of $(\mathrm{Cu}+\mathrm{Pb}) / 2$ $+\mathrm{Bi}=8 \mathrm{apfu}$, after Makovicky and Makovicky (1978). The position of these phases in the bismuthinite-aikinite series is described by the hypothetical percentage of the aikinite end member $n_{\text {aik }}=25(\mathrm{x}+\mathrm{y}) / 2$. The value of $\Delta n_{\text {aik }}$ $= \pm 12.5(\mathrm{y}-\mathrm{x})$ expresses the accuracy of the analytical data. Minor contents of $\mathrm{Pb}$ (up to 2.05 wt. \%), $\mathrm{Cu}$ (up to 1.34 wt. \%) and $\mathrm{Fe}$ (up to 1.22 wt. \%) are typical of the studied bismuthinite (Tab. 6). Calculated values of $n_{\text {aik }}=$ $3.1-7.6$ are under the upper limit of the solid-solution field of bismuthinite (e.g. Topa et al. 2002; Cook and Ciobanu 2003).

\subsection{W- and Al-rich hematite}

Hematite represents a very abundant mineral component of the studied gangue (approx. 20-30 vol. \% or even more). It forms metallic aggregates up to $2 \mathrm{~cm}$ across which consist of tabular crystals up to 2-3 $\mathrm{mm}$; small fragments shine through red. Hematite aggregates over-
Tab. 6 Chemical composition of bismuthinite (wt. \%)

\begin{tabular}{|c|c|c|c|c|c|c|}
\hline & 1 & 2 & 3 & 4 & 5 & 6 \\
\hline $\mathrm{Fe}$ & 0.19 & 1.09 & 0.10 & 0.06 & 0.08 & 1.22 \\
\hline $\mathrm{Pb}$ & 0.30 & 0.37 & 0.91 & 2.05 & 0.75 & 0.03 \\
\hline $\mathrm{Cu}$ & 0.45 & 0.59 & 0.79 & 1.19 & 1.34 & 0.42 \\
\hline $\mathrm{Bi}$ & 80.23 & 79.09 & 79.97 & 78.55 & 77.66 & 78.88 \\
\hline Se & 0.83 & 1.05 & 0.75 & 0.81 & 0.85 & 1.06 \\
\hline S & 18.53 & 18.29 & 18.69 & 18.60 & 18.66 & 18.92 \\
\hline Total & 100.35 & 99.39 & 101.12 & 101.20 & 99.26 & 99.30 \\
\hline $\mathrm{Fe}$ & 0.070 & 0.396 & 0.036 & 0.021 & 0.031 & 0.445 \\
\hline $\mathrm{Pb}$ & 0.030 & 0.036 & 0.090 & 0.203 & 0.075 & 0.003 \\
\hline $\mathrm{Cu}$ & 0.145 & 0.189 & 0.253 & 0.384 & 0.437 & 0.136 \\
\hline $\mathrm{Bi}$ & 7.878 & 7.689 & 7.811 & 7.696 & 7.728 & 7.709 \\
\hline$\Sigma \mathrm{M}$ & 8.122 & 8.311 & 8.189 & 8.304 & 8.272 & 8.291 \\
\hline Se & 0.216 & 0.271 & 0.194 & 0.210 & 0.224 & 0.274 \\
\hline $\mathrm{S}$ & 11.861 & 11.591 & 11.900 & 11.877 & 12.105 & 12.049 \\
\hline$\Sigma \mathrm{Se}+\mathrm{S}$ & 12.077 & 11.862 & 12.094 & 12.087 & 12.329 & 12.323 \\
\hline$n_{\text {aik }}$ & 3.05 & 7.78 & 4.74 & 7.59 & 6.79 & 7.28 \\
\hline$\Delta n_{\text {aik }}$ & 0.56 & -3.04 & 1.58 & 2.01 & 4.13 & -3.89 \\
\hline
\end{tabular}

Empirical formulae were calculated on the basis of $(\mathrm{Cu}+\mathrm{Pb}) / 2+\mathrm{Bi}=$ 8 apfu (Makovicky and Makovicky 1978);

$\Delta n_{\text {aik }}= \pm 12.5(\mathrm{y}-\mathrm{x})$ value expresses the accuracy of the analytical data; $n_{\text {aik }}=25(\mathrm{x}+\mathrm{y}) / 2-$ hypothetical percentage of the aikinite end member in formula $\mathrm{Cu}_{\mathrm{x}} \mathrm{Pb}_{\mathrm{y}} \mathrm{Bi}_{8-1 / 2(x+y)} \mathrm{S}_{12}$

print earlier hodrušite-bismuthinite aggregates (Fig. 3d) in the gangue. In the gangue cavities up to $1.5 \mathrm{~cm}$ across are locally abundant well-formed tabular crystals or rosettes of hematite in a size up to $2 \mathrm{~mm}$.

$\mathrm{X}$-ray powder diffraction data for hematite agree with the reference patterns from the ICDD PDF2 database (33-0664); the refined unit-cell parameters (Tab. 7) correspond to the published data for hematite with analogous Al content (Feenstra et al. 2005). The presence of $\mathrm{W}$
Tab. 7 Unit-cell parameters of hematite (for trigonal space group $R-3 c$ )

\begin{tabular}{lcccccc}
\hline & Hodruša-Hámre & Elba & synt. & synt. & synt. & synt. \\
\hline & this paper & $\begin{array}{c}\text { Blake et al. } \\
(1966)\end{array}$ & $\begin{array}{c}\text { Feenstra et al. Feenstra et al. Feenstra et al. Feenstra et al. } \\
(2005)\end{array}$ & $(2005)$ & $(2005)$ & $(2005)$ \\
\hline $\mathrm{Fe} /(\mathrm{Fe}+\mathrm{Al})$ & $0.97-1.00$ & 0.98 & 0.99 & 0.99 & 0.98 & 0.97 \\
\hline$a[\AA]$ & $5.0357(1)$ & $5.038(2)$ & $5.0445(5)$ & $5.0440(6)$ & $5.0341(4)$ & $5.0338(4)$ \\
$c[\AA]$ & $13.7536(9)$ & $13.77(1)$ & $13.805(3)$ & $13.797(3)$ & $13.746(2)$ & $13.744(2)$ \\
$V\left[\AA^{3}\right]$ & $302.04(1)$ & 302.7 & $304.24(8)$ & $303.99(8)$ & $301.67(6)$ & $301.60(6)$ \\
\hline
\end{tabular}


Tab. 8 Chemical composition of hematite (wt. \% and apfu based on 2 apfu)

\begin{tabular}{lrrrrrrrrrrrr}
\hline & \multicolumn{1}{c}{2} & \multicolumn{1}{c}{3} & \multicolumn{1}{c}{4} & \multicolumn{1}{c}{5} & \multicolumn{1}{c}{6} & \multicolumn{1}{c}{7} & \multicolumn{1}{c}{8} & \multicolumn{1}{c}{9} & \multicolumn{1}{c}{10} & \multicolumn{1}{c}{11} & \multicolumn{1}{c}{12} \\
\hline $\mathrm{MnO}$ & 0.00 & 0.00 & 0.00 & 0.00 & 0.05 & 0.00 & 0.08 & 0.00 & 0.00 & 0.00 & 0.00 & 0.00 \\
$\mathrm{Fe}_{2} \mathrm{O}_{3}$ & 97.69 & 97.27 & 96.32 & 98.40 & 97.30 & 96.81 & 96.20 & 97.09 & 97.27 & 97.09 & 95.65 & 93.92 \\
$\mathrm{Al}_{2} \mathrm{O}_{3}$ & 1.46 & 1.71 & 1.91 & 1.66 & 0.34 & 0.27 & 0.00 & 0.12 & 0.05 & 0.07 & 0.10 & 0.00 \\
$\mathrm{SiO}_{2}$ & 0.00 & 0.21 & 0.00 & 0.18 & 0.00 & 0.00 & 0.00 & 0.00 & 0.00 & 0.00 & 0.00 & 0.00 \\
$\mathrm{SnO}_{2}$ & 0.00 & 0.00 & 0.06 & 0.13 & 0.00 & 0.00 & 0.14 & 0.04 & 0.08 & 0.00 & 0.13 & 0.06 \\
$\mathrm{WO}_{3}$ & 0.18 & 0.49 & 0.55 & 0.95 & 1.46 & 2.55 & 3.07 & 3.96 & 4.21 & 4.37 & 4.96 & 4.91 \\
\hline Total & 99.33 & 99.67 & 98.84 & 101.32 & 99.15 & 99.63 & 99.49 & 101.21 & 101.61 & 101.53 & 100.84 & 98.89 \\
\hline $\mathrm{Mn}$ & 0.0000 & 0.0000 & 0.0000 & 0.0000 & 0.0011 & 0.0000 & 0.0018 & 0.0000 & 0.0000 & 0.0000 & 0.0000 & 0.0000 \\
$\mathrm{Fe}$ & 1.9530 & 1.9378 & 1.9354 & 1.9365 & 1.9778 & 1.9735 & 1.9749 & 1.9682 & 1.9682 & 1.9673 & 1.9604 & 1.9640 \\
$\mathrm{Al}$ & 0.0457 & 0.0534 & 0.0601 & 0.0510 & 0.0108 & 0.0086 & 0.0000 & 0.0037 & 0.0016 & 0.0022 & 0.0032 & 0.0000 \\
$\mathrm{Si}$ & 0.0000 & 0.0055 & 0.0000 & 0.0046 & 0.0000 & 0.0000 & 0.0000 & 0.0000 & 0.0000 & 0.0000 & 0.0000 & 0.0000 \\
$\mathrm{Sn}$ & 0.0000 & 0.0000 & 0.0006 & 0.0014 & 0.0000 & 0.0000 & 0.0015 & 0.0005 & 0.0009 & 0.0000 & 0.0014 & 0.0007 \\
$\mathrm{~W}$ & 0.0012 & 0.0033 & 0.0038 & 0.0065 & 0.0102 & 0.0179 & 0.0217 & 0.0276 & 0.0293 & 0.0305 & 0.0350 & 0.0354 \\
\hline Total & 2.0000 & 2.0000 & 2.0000 & 2.0000 & 2.0000 & 2.0000 & 2.0000 & 2.0000 & 2.0000 & 2.0000 & 2.0000 & 2.0000 \\
\hline
\end{tabular}

${ }^{\mathrm{VI}} \mathrm{Fe}^{3+}, 0.645 \AA$ (Shannon 1976). It is obvious that an $\mathrm{Fe}^{3+} \mathrm{W}^{6+}{ }_{-1}$ substitution vector requires concominant charge balance. This can be achieved by introduction of vacancies according to the scheme $2 \mathrm{Fe}^{3+} \leftrightarrow \mathrm{W}^{6+}+\square$ (Kolitsch 1998). Increased content of $\mathrm{Al}_{2} \mathrm{O}_{3}$ reaching 1.91 wt. $\%(0.06$ apfu) was found in the hematite zones that appear dark in the BSE images. Figure 7 shows that zones with an increased content of $\mathrm{Al}$ contain little $\mathrm{W}$ and vice versa. (see below) does not influence the unit-cell parameters significantly (Kolitsch 1998).

Hematite exhibits strong zoning in the BSE images (Figs 3d, 6). The lighter zones are W-bearing domains with up to $4.96 \mathrm{wt}$ \% $\% \mathrm{WO}_{3}(0.04 \mathrm{apfu})$. Similarly zoned hematite with $\mathrm{WO}_{3}$ contents up to $4.5 \mathrm{wt}$ \% from VI level of the Rozália vein was described by Kalinaj (1992). It occurred in association with $\mathrm{Cu}-\mathrm{Bi}$ minerals including hodrušite and younger ferberite and scheelite. Similarly increased $\mathrm{W}$ content in hematite is extremely unusual (Bowles et al. 2011); it has only been described in hematite from $\mathrm{Mn}-$ $\mathrm{Fe}-$ As vein mineralization at Sailauf (up to $0.8 \mathrm{wt}$. $\mathrm{WO}_{3} \%$ : Fusswinkel et al. 2013) or in supergene hematite (up to 1.5 wt. $\% \mathrm{WO}_{3}$ : Kempe and Sorokin 1988 or 1.72 wt. $\% \mathrm{WO}_{3}$ : Tarassov et al. 2002). A comparison of ionic radii shows that the radius of ${ }^{\mathrm{VI}} \mathrm{W}^{6+}, 0.60 \AA$, is quite close to that of

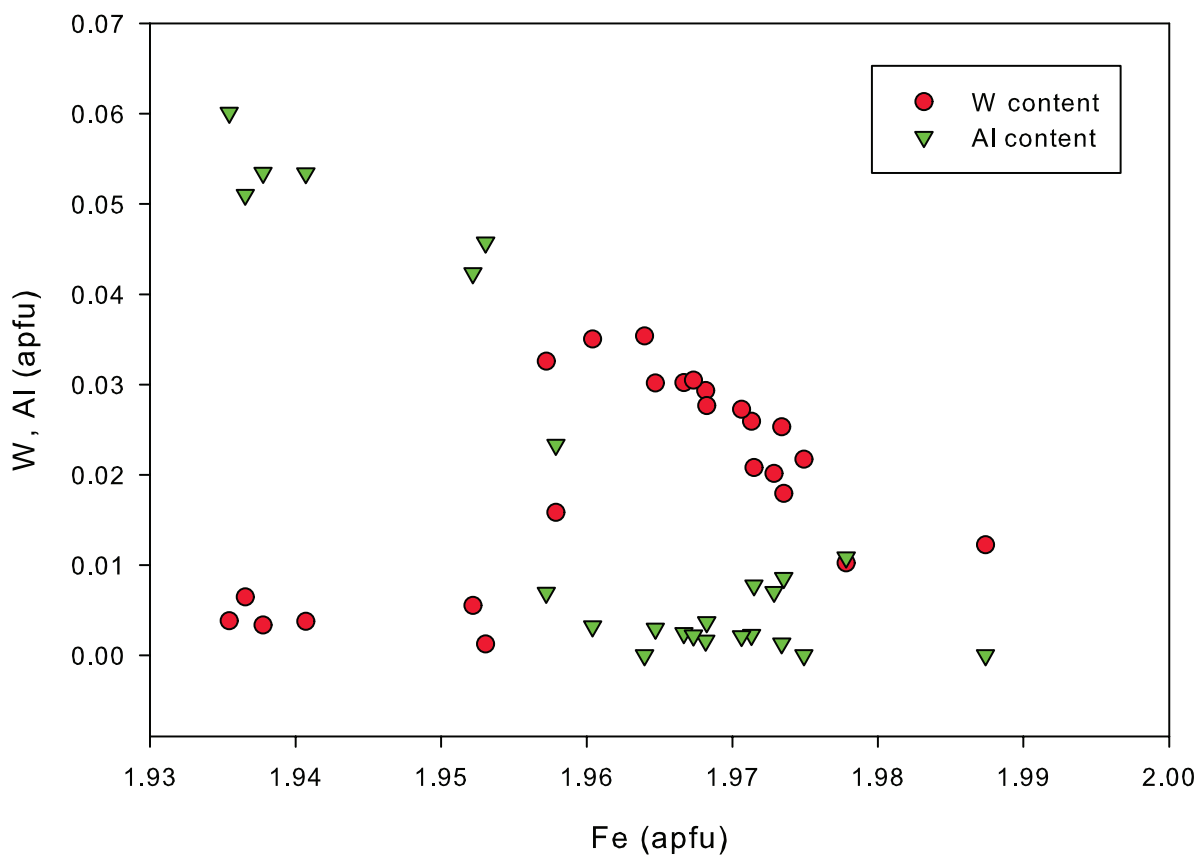

\section{Conclusions}

The newly studied gangue material with hodrušite morphologically significantly differs from the type material from Hodruša-Hámre. The hodrušite that we describe here appears in simpler mineral association, which has only traces of kupčíkite and bismuthinite. It is likely that hodrušite samples studied in the present paper originated from deeper parts of the Rozália vein (levels X-XIV), in contrast to the original type material (level VI). The columnar hodrušite aggregates are locally replaced by bismuthinite, and are thus the oldest in the studied association. Hodrušite-bismuthinite aggregates are further intensively pushed back by compositionally zoned Wand Al-rich hematite. Acicular crystals of hodrušite in cavities of the gangue are younger than bismuthinite and hematite and their origin was probably related to $\mathrm{Cu}$ and $\mathrm{Bi}$ remobilisation from the older altered gangue.

An important role of $\mathrm{Cu}-$ for-Bi substitution is indicated by the chemical composition of hodrušite; this substitution influences the calculated $N_{\text {chem }}$ values so substantially that they are practically unusable for distinguishing hodrušite from kupčíkite. The $\mathrm{Fe}$ and Ag contents are more suitable for classification of individual members of the cuprobismutite homologous series: more than 2 at. $\%$ of $\mathrm{Fe}$ are characteristic

Fig. 7 Plot of Fe vs. W and Al contents (at. \%) of hematite from Hodruša-Hámre (this study). 
of kupčíkite, more than 2 at. \% of Ag typify cuprobismutite. Hodrušite usually contains below 2 at. $\%$ of either of these elements. Increased $\mathrm{Pb}$ content can indicate the presence of other structurally close mineral phases: pizgrischite (c. 0.9 at. $\% \mathrm{~Pb})$ or paderaite $($ c. 3 at. $\% \mathrm{~Pb})$.

Hematite that is spatially associated with hodrusite is characterized by increased $\mathrm{W}$ contents, locally reaching 4.96 wt. $\% \mathrm{WO}_{3}(0.04 \mathrm{apfu})$. Such a chemistry is unusual in hematite from hydrothermal mineralizations. Tungsten probably enters the hematite crystal structure via the substitution scheme $2 \mathrm{Fe}^{3+} \leftrightarrow \mathrm{W}^{6+}+\square$.

Acknowledgements. The authors thank Milan Novák (Masaryk University, Brno) and Zdeněk Němec (Havířov) for their kind provision of material for this study. This work was financed by the Ministry of Culture of the Czech Republic (DKRVO 2014/02; National Museum 00023272) to JS and a VEGA 2/0087/12 project to SJ and also was supported by the Slovak Research and Development Agency under the contract No. APVV0375-12 for DO. Both the referees, A. R. Cabral and F. Veselovský, as well as handling editor R. Skála and editor-in-chief V. Janoušek, are acknowledged for comments and suggestions that helped greatly to improve the manuscript.

\section{References}

Anthony JW, Bideaux RA, Bladh KW, Nichols MC (2003) Handbook of Mineralogy. Volume I-Elements, Sulfides, Sulfosalts. Mineral Data Publishing, Tucson, pp 1-588

Blake RI, Hessevick RE, Zoltai T, Finger LW (1966) Refinement of the hematite structure. Amer Miner 51: 123-129

Bowles JFW, Howie RA, Vaughan DJ, Zussman J (2011) Rock-Forming Minerals. Volume 5A Non-Silicates: Oxides, Hydroxides and Sulphides, $2^{\text {nd }}$ edition. The Geological Society, London, pp 237-239

BuRnhAm CW (1962) Lattice constant refinement. Carnegie Inst Wash, Yearb 61: 132-135

Cook NJ, Ciobanu CL (2003) Lamellar minerals of the cuprobismutite series and related paděraite: a new occurrence and implications. Canad Mineral 41: 441-456

Crowley JA, Currier RH, Szenics T (1997) Mines and minerals of Peru. Mineral Record 28: 1-98

Feenstra A, Sämann S, Wunder B (2005) An experimental study of $\mathrm{Fe}-\mathrm{Al}$ solubility in the system corundum-hematite up to $40 \mathrm{kbar}$ and $1300{ }^{\circ} \mathrm{C}$. J Petrol 46: 1881-1892

Fusswinkel T, Wagner T, Wenzel T, Wälle M, Lorenz J (2013) Evolution of unconformity-related $\mathrm{Mn}-\mathrm{Fe}-\mathrm{As}$ vein mineralization, Sailauf (Germany): insight from major nad trace elements in oxide and carbonate minerals. Ore Geol Rev 50: 28-51
Jeleñ S, Háber M (1995) New Bi-sulphosalts from the Banská Štiavnica and Hodruša deposits. Bull mineralpetrolog Odd Nár Muz (Praha) 3: 37-43 (in Slovak)

Jeleñ S, Pršek S, Kovalenker VA, Topa D, Sejkora J, Števko M, Ozdín D (2012) Bismuth sulfosalts of the cuprobismutite, pavonite and aikinite series from the Rozália mine, Hodruša-Hámre, Slovakia. Canad Mineral 50: 325-340

Kalinaj M (1992) Ferberite - new mineral in the ŠtiavnicaHodruša ore field. Miner Slov 24: 471-475 (in Slovak)

KeMPe UK, Sorokin ND (1988) On the alteration of wolframite. Dokl AN SSSR, Geokhimiya 303: 203-206

KoDĚRA M (1959) Paragenetical and geochemical research of Rozália vein in Hodruša. Geol Práce 54: 225-263 (in Slovak)

KoDĚrA M (1981) Distribution of silver and bismuth in Banská Štiavnica ore veins. Geol Zbor Geol Carpath 36: 707-713

KodĚra P, LeXA J (2010) Classic localities in Central Slovakia Volcanic Field: gold, silver and base metal mineralizations and mining history at Banská Štiavnica and Kremnica. IMA Field Trip Guide SK3. Acta MineralPetrogr, Field Guide Series 29: 1-19

KodĚra M, KupČí V, Makovicky E (1970) Hodrushite a new sulphosalt. Mineral Mag 37: 641-648

Koděra P, Lexa J, Rankin AH, Fallick AE (2005) Epithermal gold veins in a caldera setting: Banská Hodruša, Slovakia. Miner Depos 39: 921-943

Kolitsch U (1998) Bernalite from the Clara mine, Germany, and the incorporation of tungsten in minerals containing ferric iron. Canad Mineral 36: 1211-1216

Kovalenker VA, Jeleñ S, Sandomirskaya S (1993) Minerals of the system $\mathrm{Ag}-\mathrm{Cu}-\mathrm{Pb}-\mathrm{Bi}-\mathrm{S}$ from the polymetallic veins of the Štiavnica-Hodruša ore field (Slovakia). Geol Carpath 44: 409-419

Kovalenker VA, Plotinskaya OY, Koneev RI (2003) Mineralogy of the epithermal gold-sulfide-telluride ores of the Kairagach gold deposit, (Uzbekistan). New Data Miner 38: 45-56

KupČí V, Maкоvicky E (1968) Die Kristallstruktur des Minerals $(\mathrm{Pb}, \mathrm{Ag}, \mathrm{Bi}) \mathrm{Cu}_{4} \mathrm{Bi}_{5} \mathrm{~S}_{11}$. Neu Jb Mineral, Mh 236-239

Kyono A, Kimata M (2004) Structural variation induced by difference of the inert pair effect in the stibnite-bismuthinite solid solution series $(\mathrm{Sb}, \mathrm{Bi})_{2} \mathrm{~S}_{3}$. Amer Miner 89: 935-940

LeXa J (2001) Metalogeny of Štiavnica stratovulcano. Miner Slov 33: 203-214 (in Slovak)

LeXa J, ŠTohl J, KoneČNÝ V (1999) Banská Štiavnica ore district: relationship among metallogenetic processes and the geological evolution of a stratovolcano. Miner Depos 34: 639-665

Makovicky E, MacLean WH (1972) Electron microprobe analysis of hodrushite. Canad Mineral 11: 504-513 
Makovicky E, Makovicky M (1978) Representation of composition in the bismuthinite-aikinite series. Canad Mineral 16: 405-409

Márquez-Zavalía MF, Galliski MA, Černý P, Chapman $\mathrm{R}$ (2012) An assemblage of bismuth-rich, telluriumbearing minerals in the El Quemado granitic pegmatite, Nevados de Palermo, Salta, Argentina. Canad Mineral 50: 1489-1498

Meisser N, Schenk K, Berlepsch P, Brugger J, Bonin M, Criddle AJ, Thélin P, Bussy F (2007) Pizgrischite, $(\mathrm{Cu}, \mathrm{Fe}) \mathrm{Cu}_{14} \mathrm{PbBi}_{17} \mathrm{~S}_{35}$, a new sulfosalt from the Swiss Alps: description, crystal structure nad occurrence. Canad Mineral 45: 1229-1245

ONDRUŠ P (1993) A computer program for analysis of Xray powder diffraction patterns. Materials Sci Forum, EPDIC-2, Enchede, 133-136: 297-300

PieczKaA, GoŁęBIOwska B (2012) Cuprobismutite homologues in granitic pegmatites from Szklarska Poręba, Karkonosze Massif, southwestern Poland. Canad Mineral 50: 313-324

Pouchou JL, PIchoir F (1985) "PAP” ( $\varphi \rho Z)$ procedure for improved quantitative microanalysis. In: ArMStrong JT (ed) Microbeam Analysis. San Francisco Press, San Francisco, pp 104-106

Pršek J, Mikuš T, Makovicky E, Chovan M (2005) Cuprobismutite, kupčíkite, hodrushite and associated sulfosalts from the black shale hosted Ni-Bi-As mineralization at Čierna Lehota, Slovakia. Eur J Mineral 17: 155-162

Sejkora J, Ozdín D, Laufek F, Plášil J, Litochleb J (2011) Marrucciite, a rare Hg-sulfosalt from the Gelnica ore deposit (Slovak Republic), and its comparison with the type occurrence at Buca della Vena mine (Italy). J Geosci 56: 399-408

SHANNON RD (1976) Revised effective ionic radii and systematic study of interatomic distances in halides and chalcogenides. Acta Cryst A32: 751-767

Tarassov M, Mihailova B, Tarassova E, Konstantinov L (2002) Chemical composition and vibrational spectra of tungsten-bearing goethite and hematite from Western Rhodopes, Bulgaria. Eur J Mineral 14: 977-986

Topa D, Makovicky E (2006) The crystal structure of paděraite, $\mathrm{Cu}_{7}\left(\mathrm{X}_{0.33} \mathrm{~Pb}_{1.33} \mathrm{Bi}_{11.33}\right)_{\Sigma 13} \mathrm{~S}_{22}$, with $\mathrm{X}=\mathrm{Cu}$ or Ag: new data and interpretation. Canad Mineral 44: 481-495

Topa D, Makovicky E, PaAr WH (2002) Composition ranges and exsolution pairs for the members of the bismuthinite-aikinite series from Felbertal, Austria. Canad Mineral 40: 849-869

Topa D, Makovicky E, Balič-Zunič T (2003a) Crystal structures and crystal chemistry of members of the cuprobismutite homologous series of sulfosalts. Canad Mineral 41: 1481-1501

Topa D, Makovicky E, Balič-Zunič T, Paar WH (2003b) Kupčíkite, $\mathrm{Cu}_{3.4} \mathrm{Fe}_{0.6} \mathrm{Bi}_{5} \mathrm{~S}_{10}$, a new sulfosalt from Felbertal, Austria, and its crystal structure. Canad Mineral 41: 1155-1166

Yvon K, Jeitschko W, Parthé E (1977) Lazy Pulverix, a computer program for calculation X-ray and neutron diffraction powder patterns. J Appl Cryst 10: 73-74 